\title{
Prevalence of Hepatitis B among Students from the University of Lomé, Togo in 2015
}

\author{
Didier K. Ekouevi1,2,3*, Anne Thomas ${ }^{3}$, Dieudonné Sewu33 ${ }^{3}$, Late Lawson-Ananissoh4, \\ Boris Tchounga $^{5}$, Mounerou Salou' ${ }^{6}$, Guillaume Ketoh' ${ }^{1}$, Mireille David ${ }^{6}$, Patrick A. Coffie ${ }^{5,7}$, \\ Datouda Redah4
}

${ }^{1}$ Département de Santé Publique, Université de Lomé, Lomé, Togo

${ }^{2}$ Centre Inserm Unité 1219, Université de Bordeaux, Bordeaux, France

${ }^{3}$ Centre Africain de Recherche en Epidémiologie et en Santé Publique (CARESP), Lomé, Togo

${ }^{4}$ Service de Gastro-Entérologie, CHU Campus, Université de Lomé, Lomé, Togo

${ }^{5}$ Program PACCI/LIA Inserm, Abidjan, Côte d'Ivoire

${ }^{6}$ Laboratoire BIOLIM, Université de Lomé, Lomé, Togo

${ }^{7}$ Département de Dermatologie et Infectiologie, Université Felix Houphouët Boigny, Abidjan, Côte d'Ivoire

Email: ${ }^{*}$ Didier.ekouevi@gmail.com

How to cite this paper: Ekouevi, D.K., Thomas, A., Sewu, D., Lawson-Ananissoh, L., Tchounga, B., Salou, M., Ketoh, G., David, M., Coffie, P.A. and Redah, D. (2017) Prevalence of Hepatitis B among Students from the University of Lomé, Togo in 2015. Open Journal of Epidemiology, 7, 262-272. https://doi.org/10.4236/ojepi.2017.73020

Received: May 25, 2017

Accepted: August 19, 2017

Published: August 22, 2017

Copyright $\odot 2017$ by authors and Scientific Research Publishing Inc. This work is licensed under the Creative Commons Attribution International License (CC BY 4.0).

http://creativecommons.org/licenses/by/4.0/

c) (i) Open Access

\begin{abstract}
Objective: Hepatitis B virus (HBV) is endemic in sub-Saharan Africa where more than 80 million subjects are chronic carriers. However, screening is not systematic in the population and prevalence data are scarce, especially among the youth population. The objective of this study was to estimate the prevalence of HBV and its correlates among first-year University students at the University of Lomé. Study design: A cross-sectional survey was conducted between November 2015 and January 2016 at the University of Lomé during the annual checkup offered to newly enrolled students. Method: A self-administered questionnaire was used to collect data on demographics and sexual behaviors, and rapid tests were used for the detection of Antigen $\mathrm{HB}_{\mathrm{S}}$ (HBsAg) and HIV in each participant. A logistic regression model was performed to identify factors associated with $\mathrm{HBsAg}$ positivity. Results: A total of 800 students (56.2\% were men) were screened among 1505 students who participated in the study. The median age was 20 years (IQR: [18 - 21]). The overall prevalence of HBsAg was 4.6\% (95\% CI: [3.2 - 6.3]): 5.8\% among men and $3.1 \%$ among women $(\mathrm{p}=0.04)$. The prevalence of HIV was $0.8 ; 95 \% \mathrm{CI}$ $[0.3 \%-1.6 \%]$ and one case $(0.1 \%)$ of coinfection HIV and HBV was identified. Factors associated with $\mathrm{HBsAg}$ positivity were male gender [adjusted Odds Ratio $(\mathrm{aOR})=2.08,95 \%$ CI: $1.02-5.00, \mathrm{p}=0.0447]$ and ever having a sexual relationship $[\mathrm{aOR}=2.44 ; 95 \% \mathrm{CI}=1.11-5.78, \mathrm{p}=0.0264]$. Conclusion: This study among university students demonstrates that the prevalence of HBV is high among this population and that there is a need for prevention programs to target this vulnerable population. This is an additional argument
\end{abstract}


toward HBV screening and treatment among students during annual health check.

\section{Keywords}

Hepatitis B, Prevalence, West-Africa, Students

\section{Introduction}

The World Health Organization (WHO) estimates at more than 2 billion the number of people infected with the Hepatitis B Virus (HBV) in the World [1]. An estimated 240 million people are chronic carriers of HBV, making HBV infection the tenth leading cause of death. More than 600,000 people die every year from complications of hepatitis B [1]. Liver cancer is the worst consequence of $\mathrm{HBV}$ infection and is the second leading cause of deaths due to cancer in the World [1] [2] [3]. Sub-Saharan Africa (SSA) has the highest prevalence of Hepatitis B with 80 million people carriers of $\mathrm{HBV}$ [4] and a prevalence ranging from $5 \%$ to $10 \%$ in the adult population [1]. Despite HBV prevalence being relatively high in SSA, screening and treatment is still limited or rare in this region [5].

In SSA, HBV is most commonly transmitted from mother-to child at birth (perinatal transmission) or through horizontal transmission (exposure to infected blood), especially from an infected child to an uninfected child during the first 5 years of life [1] [6] [7] [8] [9]. Sexual transmission of HBV, which is scarcely documented, could also occur among healthy adults particularly when unvaccinated people engage in risky sexual behaviors [1]. The main complication of HBV infection is the occurrence of hepatic cirrhosis that lead to hepatocellular carcinoma especially when transmission occurs before the age of 5 [10] [11] [12]. To avoid HBV transmission during childhood, the HBV vaccine was introduced in the expanded program on immunization (EPI) in several countries of SSA in the years 2000. In Togo, the HBV vaccine was introduced into the National EPI in 2008.

Very few data on the prevalence of HBV in the general population exist in Togo. One study conducted among people living with HIV in 2011 estimated the HBV prevalence at 9.7\% [4]. Another study among prisoners in 2013 estimated the prevalence at $12.5 \%$, while a study among individuals in a hospital in Lomé found a prevalence as high as $19.1 \%$ [5] [13]. However, no study in Togo has so far specifically focused on the prevalence of HBV among youth and university students, who could be considered a vulnerable population. The objective of this study was to estimate the prevalence of $\mathrm{HBV}$ and to determine its associated factors among first-year students of the University of Lomé, in Togo.

\section{Method}

\subsection{Study Design}

Across-sectional survey was conducted among first-year students enrolled at the 
University of Lomé, during the academic year 2015-2016. The participants were enrolled from November 23, 2015, to January 29, 2016 in the Division of Preventive Medicine of the University of Lomé.

\subsection{Study Population and Sampling}

The study population was students in their first year presenting themselves for their mandatory health check-up. A consecutive recruitment occurred during this period of data collection. We included all students coming from preventive medicine for their check-up from November 2015 to January 2016. Among them, we randomly selected 800 for biological tests of HBV and HIV. Inclusion criteria were: 1) to be student in the first year, 2) attending check-up visit, ii) signing a consent form to participate in the study. The criteria of non-inclusion was the refusal to participate in the study.

\subsection{Data Collection}

A self-administered questionnaire was provided to each participant, to collect data on socio-demographic characteristics, consumption of addictive substances, and sexual behaviors. Participants took 10 to 15 minutes to complete it. Prior to the beginning of the study, the questionnaire was tested on 20 students to ensure questions were appropriate and to reformulate as needed.

\subsection{Biological Analyses}

The rapid test Determine $\mathrm{HBsAg}^{\circledR}$ (Alere determined ${ }^{\mathrm{TM}} \mathrm{HBsAg}$, Waltham, MA, USA) was used for the measurement of HBs Antigen. It is a dipstick test for the qualitative detection of $\mathrm{HBsAg}$ and has a sensitivity of $85 \%$ and a specificity of $100 \%$ [14]. HIV screening is based on the recommended national algorithm Determine HIV-1/2 (Abbott Diagnostics) and First Response HIV Card test 1 - 2.0 (PMC Medical). A student was considered as living with HIV when both tests were positive. In case of no concordance of the two tests, the blood sample was sent to the national reference laboratory for an ELISA test.

\subsection{Data Processing}

The data from the questionnaire were entered and stored in a Microsoft Office Access 2007 database. Prior to analysis, all data were checked and cleared. The statistical analysis was performed with $\mathrm{R}$ software version 3.3.2. Statistical analysis included a descriptive analysis of students who had their HBsAg results available and a comparative analysis based on HBsAg positivity. Descriptive analysis consisted of frequencies and proportions, or median and interquartile range (IQR). A comparative analysis was also conducted to assess the difference between variables collected depending on the availability of the HBsAg results. The statistical tests used was the Mann Whitney/Wilcoxon test for the quantitative variables. Univariate and multivariate logistic regression were conducted to assess risk factors associated with HbsAg positivity. Explanatory variables were: 
sex, age, location (urban or rural setting) financial status, education level, history of sexual intercourse, alcohol consumption. The threshold of significance was set at 0.05 . Missing data were not taken into account in the analyses.

\subsection{Ethical Aspects}

Ethical approval was granted on November 2015 by the Bioethics Committee for Research in Health in Togo (No. 513/2015/MSPS/CAB/SG/DPLET/CBRS). An information sheet and informed consent form were provided to each student to explain the purpose of the study and to obtain their agreement to participate. Each student was considered as included in the study once they signed the consent form. The anonymity of the students participating in the study was maintained and an identification number was assigned to each respondent. The data collected was stored in a secure location and the database was protected from access with passwords.

\section{Results}

\subsection{Sociodemographic Characteristics}

During the study period, 1505 students came for their annual health check. For financial reason, 800 blood samples were randomly selected for Hepatitis B including $56.2 \%$ of males $(n=450)$ and $43.8 \%$ of females $(n=350)$. There was no statistical difference between the students included in the study and those not included for the main demographic and behavioral variables. The median age was 20 years old (IQR: [18 - 21]). Almost all students were single (99.1\%), 60.5\% students lived in urban areas and $2.4 \%$ reported smoking. Approximately half of students (47.7\%) reported ever having sexual intercourse and among them the number of partners reported the last 12 months was one IQR [1 - 1]. This number was similar in men and women.

The other sociodemographic characteristics are presented in Table 1.

\subsection{Prevalence of HBV}

Out of 800 students tested for HBV, 37 were identified as being HBsAg-positive with a prevalence of $4.6 \%(95 \% \mathrm{CI}[3.2 \%-6.3 \%])$. This prevalence was higher in males (5.8\%) than in females (3.1\%), although the difference was not statistically significant $(\mathrm{p}=0.07)$. The prevalence of HBsAg was unevenly distributed among the different age groups and was lower among those less than 18 years old (1.3\%) compared to those aged between 18 and $20(6.9 \%)$ and those 20 years old and older (5.3\%; $\mathrm{p}=0.01$ ) (Table 2). There was no significant association between the consumption of addictive substances and being HBsAg positive (Table 2). Hepatitis B prevalence was $5.7 \%$ in participants who ever had sexual intercourse vs $2.7 \%$ among students who were not yet sexually active $(\mathrm{p}=0.037)$.

\subsection{HBV and HIV Coinfection}

A total of six students were HIV positive with a prevalence of $0.8 \% 95 \mathrm{CI}[0.3 \%$ - 
Table 1. Sociodemographic characteristics $(\mathrm{N}=800)$.

\begin{tabular}{|c|c|c|}
\hline Characteristics & $\mathrm{n}$ & $\%$ \\
\hline \multicolumn{3}{|l|}{$\operatorname{Sex}(n=800)$} \\
\hline Male & 450 & 56.2 \\
\hline Female & 350 & 43.8 \\
\hline \multicolumn{3}{|l|}{ Age (years) $(n=800)$} \\
\hline$<18$ & 101 & 12.6 \\
\hline $18-20$ & 399 & 49.9 \\
\hline $21-23$ & 228 & 28.5 \\
\hline$>23$ & 72 & 9.0 \\
\hline \multicolumn{3}{|l|}{ Marital status $(n=796))$} \\
\hline Married/cohabiting & 3 & 0.4 \\
\hline Single & 789 & 99.1 \\
\hline Divorced/Widowed & 4 & 0.5 \\
\hline \multicolumn{3}{|c|}{ Educational level of head of family $(n=778)$} \\
\hline Primary school & 82 & 10.5 \\
\hline Secondary school & 327 & 42.0 \\
\hline University/College & 236 & 30.3 \\
\hline Never went to school & 35 & 4.5 \\
\hline Don’t know & 98 & 12.6 \\
\hline \multicolumn{3}{|l|}{ Living setting $(\mathrm{n}=782)$} \\
\hline Urban & 473 & 60.5 \\
\hline Semi-Urban & 163 & 20.8 \\
\hline Rural & 146 & 18.7 \\
\hline \multicolumn{3}{|c|}{ Perception of financial status $(n=770)$} \\
\hline Comfortable/Sufficient income & 473 & 61.4 \\
\hline Poor or very poor & 297 & 38.6 \\
\hline \multicolumn{3}{|l|}{ Ever had sexual intercourse $(n=774)$} \\
\hline Yes & 369 & 47.7 \\
\hline No & 405 & 52.3 \\
\hline \multicolumn{3}{|l|}{ Smoking $(n=787)$} \\
\hline Rarely & 19 & 2.4 \\
\hline Never & 768 & 97.6 \\
\hline \multicolumn{3}{|l|}{ Alcohol Consumption $(n=780)$} \\
\hline Several times/week & 3 & 0.4 \\
\hline Several times/month & 6 & 0.8 \\
\hline Rarely & 342 & 43.8 \\
\hline Never & 429 & 55.0 \\
\hline \multicolumn{3}{|l|}{ Drugs $(\mathrm{n}=780))$} \\
\hline Several times/month & 1 & 0.1 \\
\hline Rarely & 6 & 0.8 \\
\hline Never & 773 & 99.1 \\
\hline
\end{tabular}


Table 2. Description of socio-demographic characteristics based on AgHBs positivity.

\begin{tabular}{|c|c|c|c|c|c|c|c|}
\hline \multirow[t]{2}{*}{ Characteristics } & \multicolumn{2}{|c|}{ Total $(\mathrm{n}=800)$} & \multicolumn{2}{|c|}{ AgHBs+ $(n=37)$} & \multicolumn{2}{|c|}{ AgHBs- $(n=763)$} & \multirow[t]{2}{*}{$P$ value } \\
\hline & $N=800$ & $\mathrm{n}(\%)$ & $N=37$ & n (\%) & $N=763$ & $\mathrm{n}(\%)$ & \\
\hline Sex & $N=800$ & & & & & & 0.0784 \\
\hline Male & & $450(56.3)$ & & $26(70.3)$ & & $424(55.6)$ & \\
\hline Female & & $350(43.7)$ & & $11(29.7)$ & & $339(44.4)$ & \\
\hline Age (years). median & $N=800$ & & $N=37$ & & $N=763$ & & 0.0152 \\
\hline Median [IQR] & & $20[18-21]$ & & $20[20-22]$ & & $20[18-21]$ & \\
\hline Age (years). quartile & $N=800$ & & $N=37$ & & $N=763$ & & 0.0093 \\
\hline$\leq 18$ & & $238(29.8)$ & & $3(8.1)$ & & $235(30.8)$ & \\
\hline$[18-20]$ & & $262(32.7)$ & & $18(48.7)$ & & $244(32.0)$ & \\
\hline$[20-21]$ & & $102(12.8)$ & & $6(16.2)$ & & $96(12.6)$ & \\
\hline$[21-31]$ & & $198(24.7)$ & & $10(27.0)$ & & $188(26.6)$ & \\
\hline Marital Status & $N=796$ & & $N=37$ & & $N=759$ & & 0.2843 \\
\hline Married/Cohabitating & & $3(0.4)$ & & $0(0.0)$ & & $3(0.4)$ & \\
\hline Single & & $789(99.1)$ & & $36(97.3)$ & & $753(99.2)$ & \\
\hline Widowed/Divorced/Separated & & $4(0.5)$ & & $1(2.7)$ & & $3(0.4)$ & \\
\hline Living setting/Place of origin & $N=782$ & & $N=35$ & & $N=747$ & & 0.0488 \\
\hline Urban & & $473(60.5)$ & & $18(51.4)$ & & $455(60.9)$ & \\
\hline Semi-urban & & $163(20.8)$ & & $5(14.3)$ & & $158(21.2)$ & \\
\hline Rural & & $146(18.7)$ & & $12(34.3)$ & & $134(17.9)$ & \\
\hline Perception of Financial status & $N=770$ & & $N=36$ & & $N=734$ & & 0.0391 \\
\hline Comfortable & & $176(22.9)$ & & $6(16.7)$ & & $170(23.2)$ & \\
\hline Sufficient income & & $297(38.6)$ & & $9(25.0)$ & & $288(39.2)$ & \\
\hline Poor & & $271(35.2)$ & & $21(58.3)$ & & $250(34.1)$ & \\
\hline Very poor & & $26(3.3)$ & & $0(0.0)$ & & $26(3.5)$ & \\
\hline Tobacco consumption & $N=787$ & & $N=35$ & & $N=752$ & & 0.2121 \\
\hline Everyday & & - & & - & & - & \\
\hline Several times/week & & - & & - & & - & \\
\hline Several times/month & & - & & - & & - & \\
\hline Rarely & & $19(2.4)$ & & $0(0.0)$ & & $19(2.5)$ & \\
\hline Never & & $768(97.6)$ & & $35(100.0)$ & & $733(97.5)$ & \\
\hline Alcohol consumption & $N=780$ & & $N=35$ & & $N=745$ & & 0.9999 \\
\hline Everyday & & - & & - & & - & \\
\hline Several times/week & & $3(0.4)$ & & $0(0.0)$ & & $3(0.4)$ & \\
\hline Several times/month & & $6(0.8)$ & & $0(0.0)$ & & $6(0.8)$ & \\
\hline Rarely & & $342(43.8)$ & & $15(42.9)$ & & $327(43.9)$ & \\
\hline Never & & $429(55.0)$ & & $20(57.1)$ & & 409 (54.9) & \\
\hline Drugs consumption & $N=780$ & & $N=35$ & & $N=745$ & & 0.9999 \\
\hline Everyday & & - & & - & & - & \\
\hline Several times/week & & - & & - & & - & \\
\hline Several times/month & & $1(0.1)$ & & $0(0.0)$ & & $1(0.1)$ & \\
\hline Rarely & & $6(0.8)$ & & $0(0.0)$ & & $6(0.8)$ & \\
\hline Never & & $773(99.1)$ & & $35(100.0)$ & & $738(99.1)$ & \\
\hline
\end{tabular}


$1.6 \%])$. There is one $(0.1 \%)$ case of coinfection of HBV and HIV.

\subsection{Factors Associated with the Positivity of HBsAg}

In multivariate analysis, two variables were associated with HBsAg positivity: male gender $(\mathrm{aOR}=2.08,95 \%$ CI $[1.02-5.00], \mathrm{p}=0.0047)$ and ever having a sexual relationship $(\mathrm{aOR}=2.44 ; 95 \% \mathrm{CI}[1.11-5.78]), \mathrm{p}=0.0264)($ Table 3$)$.

\section{Discussion}

This is the first study of hepatitis B prevalence study among university students in Togo which yielded aHBV prevalence of $4.6 \%$. Two factors were significantly associated with HbsAg: gender and ever having sexual intercourse.

Previous studies in Togo reported a HBV prevalence ranging approximately between $9 \%$ to $19 \%$ [4] [5] [13]. These studies were mainly conducted among specific group of people with different characteristics in terms of age, sexual activity, matrimonial status, morbidity, etc. It is therefore difficult to compare the

Table 3. Factors associated to AgHBs+ among University students of the University of Lome. Univariate and Multivariate analysis $(\mathrm{n}=770)$

\begin{tabular}{|c|c|c|c|c|c|c|c|c|}
\hline \multirow{2}{*}{ Characteristics } & \multicolumn{5}{|c|}{ Univariate Analysis } & \multicolumn{3}{|c|}{ Final Model (Multivariate analysis) } \\
\hline & $\mathrm{n} / \mathrm{N}$ & $\%$ & OR & $95 \% \mathrm{CI}$ & $P$ values & AOR & $\mathrm{C} 95 \% \mathrm{CI}$ & $P$ values \\
\hline Sex, $\mathrm{n}=800$ & & & & & 0.0829 & & & 0.0447 \\
\hline Females & $11 / 350$ & 3.1 & 1.00 & & & 1.00 & & \\
\hline Males & $26 / 450$ & 5.8 & 1.89 & {$[0.94-4.04]$} & & 2.08 & {$[1.02-5.00]$} & \\
\hline Age (years). Median, $n=800$ & & & & & 0.0077 & & & \\
\hline$[16-18]$ & $3 / 238$ & 1.3 & 1.00 & & & & & \\
\hline$[18-31]$ & $34 / 562$ & 6.1 & 5.04 & {$[1.79-21.10]$} & & & & \\
\hline Living setting. $n=782$ & & & & & 0.0727 & & & 0.2054 \\
\hline Urban & $18 / 473$ & 3.8 & 1.00 & & & 1.00 & & \\
\hline Semi-urban & $5 / 163$ & 3.1 & 0.80 & {$[0.26-2.04]$} & & 0.73 & {$[0.23-1.95]$} & \\
\hline Rural & $12 / 146$ & 8.2 & 2.26 & {$[1.04-4.77]$} & & 1.43 & {$[0.58-3.39]$} & \\
\hline Educational level of head of family, $n=778$ & & & & & 0.9014 & & & \\
\hline Primary school/never went to school/Don't know & $9 / 215$ & 4.2 & 1.00 & & & & & \\
\hline Secondary & $15 / 327$ & 4.6 & 1.10 & {$[0.48-2.66]$} & & & & \\
\hline University & $12 / 236$ & 5.1 & 1.23 & {$[0.51-3.06]$} & & & & \\
\hline Alcohol consumption. $\mathrm{n}=\mathbf{7 8 0}$ & & & & & 0.7943 & & & \\
\hline Never & $20 / 429$ & 4.7 & 1.00 & & & & & \\
\hline Several times/week or month/Rarely & $15 / 351$ & 4.3 & 0.91 & {$[0.45-1.80]$} & & & & \\
\hline Ever had sexual intercourse, $n=774$ & & & & & 0.0422 & & & 0.0264 \\
\hline No & $11 / 405$ & 2.7 & 1.00 & & & 1.00 & & \\
\hline Yes & $21 / 369$ & 5.7 & 2.16 & {$[1.05-4.71]$} & & 2.44 & {$[1.11-5.78]$} & \\
\hline
\end{tabular}

OR: Odds Ratio, AOR: Adjusted Odds Ratio; 95\% CI: 95\% Confidence Interval; N: Denominator in the population and n numerator (number of subject with HBgAs+). 
prevalence of those previous studies with the prevalence among University students in Lomé. Some studies in SSA showed a comparable HBV prevalence among youth [15] [16]. A study conducted at the University of Bangui among 801 students in 2007 found a prevalence of HbsAg positivity of 1.3\% [17]. Mboto and Edet [18] found a similar prevalence of $4.7 \%$ among 150 students at the University of Uyo, Nigeria. In another study completed from 2011 to 2014 in The Gambia, a prevalence of $3.1 \%$ was found among male blood donors between the ages of 16 and 19 [19]. In addition, the data from the PROLIFICA study indicates that the prevalence of HBsAg positivity increased with age among men from the blood bank and men from the community to reach a peak between 30 and 39 years old then decline after this age [20]. In our study, a similar trend was observed with a higher prevalence among students older than 18 compared to those 18 years old and younger (6.1\% versus $1.3 \%$ ).

Other studies have reported that this high rate of infection with hepatitis $B$ among youth could be attributed to riskysexual behaviors such as multiple sexual partners, tattoos and piercings, although the difference was marginally significant [17]. In our study, we did not collect data on tattoos and piercing to document an association with hepatitis B.

The prevalence of HBV was on average twice as high among young people who ever had sexual intercourse. The role of sexual transmission in Hepatitis B infection is less explored. A study conducted in South Korea reported that in non-vaccinated populations, sexual transmission may increase the prevalence of HBV infection among adolescents ( $\mathrm{OR}=1.8$; CI 95\%: $1.1-2.8)$ and youth 18 to 20 years old $(\mathrm{OR}=1.90 ; \mathrm{CI} 95 \%=[1.01-3.57])[20]$. Another study in Uganda reported that having 3 or more lifetime partners was significantly associated with HBV infection among an adult population [21]. Hence, sexual transmission of $\mathrm{HBV}$ is not negligible and cohort studies should be initiated to understand the impact of sexual transmission in HBV infection.

Many studies have already reported a higher prevalence of HBV in men compared to women [13] [20] [21]. In Lemoine's study, the prevalence of hepatitis B among men was $10.5 \%$ compared to $7.6 \%$ among women $(\mathrm{p}=0.004)$. Similar results were reported in our study with the prevalence of HBV higher among men than women $(\mathrm{p}=0.08)$. The reasons for this difference in the prevalence of HBV by gender is not widely known. One explanation could be the earlier sexual debut and amore frequent sexual activity among boys [22].

In SSA, access to antiviral drugs, including tenofovir and entecavir that are the most potent drugs for HBV viral suppression, is restricted to HIV-infected individuals [23]. Hence, the only possibility is to vaccinate children against HBV with a vaccine that is only usable after the sixth week. However, perinatal transmission is major in countries of West Africa [1] [24] [25]. The screening of pregnant women could be the start point for the screening of families, in case of a positive result.

One of the limitations of our study is the use of a single positive Antigen HBs instead of two results spaced within six months to detect a chronic carrier of an- 
tigenemia HBs. Another limitation is the use of an anonymous survey which did not allow for tracking of records, especially transfer across other health centers to estimate the eligibility for antiviral treatment. The PROLIFICA study estimates that $5 \%$ of chronic carriers were eligible for antiviral treatment [19]. Finally, the HBV viral load was not performed to estimate occult hepatitis whose prevalence in Africa varies between $10 \%$ and $88 \%$ [26] [27]. Therefore, the prevalence of $\mathrm{HBV}$ in this population could probably be underestimated especially when the sensitivity of the rapid test for HBVvaries between 86\% - 96\% [28].

This study led to the inclusion of HbsAg screening into students' annual health check (package) and to reinforce advocacy for more access to HBV treatment in Togo as well as vaccination of children at birth. In addition, a nationwide $\mathrm{HBV}$ prevalence evaluation study is necessary in the short term by taking into account the date of introduction of the Hepatitis B vaccine in the EPI in order to estimate the prevalence of HBV in Togo and evaluate the impact of this vaccine. Monitoring data in the general population is also required for epidemiological tracking of this pandemic. Some Asian countries see the prevalence of HBV and the hepatocellular carcinoma decrease due to vast children's immunization programs. Unfortunately, this is not the case in SSA where halting perinatal transmission could be a realisticgoal [25] [28].

\section{Conclusion}

In conclusion, we reported high prevalence of hepatitis B among students at the University of Lome, and a relationship between sexual activity and HBV infection. Therefore, immediate and appropriate interventions should be designed and implemented across African University campuses. These actions, including awareness of safe sexual behaviors, access and availability of condoms and a reduction of the cost of immunization could contribute to reduce the transmission of HBV among young students.

\section{Acknowledgements}

We acknowledge the students who agreed to participate in the study and Alexandra Anderson who edited and commented on a different version of the manuscript. This study was funded by the NGO Centre Africain de Recherche en Epidémiologie et Santé Publique (CARESP) du Togo.

\section{Statement}

The authors have no conflict interest to declare.

\section{References}

[1] World Health Organization (2016) Hepatitis B Factsheet. World Health Organization, Geneva. http://www.who.int/mediacentre/factsheets/fs204/en/

[2] Feray, C. (2015) Hepatitis B in Africa: A Forgotten Epidemic. Humanitarian, 40, 6873. 
[3] Schweitzer, A., Horn, J., Mikolajczyk, R.T., Krause, G. and Ott, J.J. (2015) Estimates of Worldwide Prevalence of Chronic Hepatitis B Virus Infection: A Systematic Review of Data Published between 1965 and 2013. The Lancet, 386, 1546-1555.

[4] Patassi, A., Benaboud, S., Landoh, D., Salou, M., Dagnra, A., Saka, B., et al. (2016) Hepatitis B Infection in HIV-1-Infected Patients Receiving Highly Active Antiretroviral Therapy in Lomé, Togo: Prevalence and Molecular Consequences. South African Medical Journal, 106, 634-639. https://doi.org/10.7196/SAMJ.2016.v106i6.10312

[5] Jaquet, A., Wandeler, G., Tine, J., Dagnra, C.A., Attia, A., Patassi, A., et al. (2016) HIV Infection, Viral Hepatitis and Liver Fibrosis among Prison Inmates in West Africa. BMC Infectious Diseases, 16, 249.

https://doi.org/10.1186/s12879-016-1601-4

[6] Howell, J., Lemoine, M. and Thursz, M. (2014) Prevention of Materno-Fetal Transmission of Hepatitis B in Sub-Saharan Africa: The Evidence, Current Practice and Future Challenges. Journal of Viral Hepatitis, 21, 381-396.

https://doi.org/10.1111/jvh.12263

[7] Nacos, B., Dao, B. and Dahourou, M. (2000) Hepatitis B Surface Antigen Carriers State in Pregnant Women in Bobo-Dioulasso (Burkina Faso). Dakar Medical, 45, 188-190.

[8] Agbede, O., Iseyini, J., Kashanga, M. and Ojuawo, A. (2007) Risk Factors and Seroprevalence of Hepatitis B Surface Antigens in Mothers and Their Pre-School Age Children in Ilorin, Nigeria. Therapy, 4, 67-72. https://doi.org/10.2217/14750708.4.1.67

[9] Dawaki, S. and Kawo, A. (2006) Seroprevalence of Hepatitis B Surface Antigen (HbsAg) in Pregnant Women Attending Year Urban Maternity Hospital in Kano, Northern Nigeria. Nigerian Journal of Microbiology, 20, 705-709.

[10] Shimakawa, Y., Yan, H.J., Tsuchiya, N., Hall, C. and Bottomley, A.J. (2013) Association of Early Age at Establishment of Chronic Hepatitis B Infection with Persistent Viral Replication, Liver Cirrhosis and Hepatocellular Carcinoma: A Systematic Review. PLOS ONE, 8, e69430. https://doi.org/10.1371/journal.pone.0069430

[11] Kirk, G.D., Lesi, O.A., Mark, M., Akano, A.O., Sam, O., Goedert, J.J., et al. (2004) The Gambia Liver Cancer Study: Infection with hepatitis B and C and the Risk of Hepatocellular Carcinoma in West Africa. Hepatology, 39, 211-219. https://doi.org/10.1002/hep.20027

[12] Thursz, M., Cooke, G.S. and Hall, A.J. (2010) Hepatitis B Treatment in Resource Poor Settings: Time for Action. Tropical Medicine \& International Health, 15, 2-4.

[13] Kolou, M., Katawa, G., Salou, M., Gozo-Akakpo, K.S., Dossim, S., Kwarteng, A., et al. (2017) High Prevalence of Hepatitis B Virus Infection in the Age Range of 20-39 Years Old Individuals in Lomé. The Open Virology Journal, 11, 1-7. https://doi.org/10.2174/1874357901710011001

[14] Njai, H.F., Shimakawa, Y., Sanneh, B., Ferguson, L., Ndow, G., Mendy, M., et al. (2015) Validation of Rapid Point-of-Care (POC) Tests for Detection of Hepatitis B Surface Antigen in Field Laboratory Settings in Gambia, Western Africa. Journal of Clinical Microbiology, 53, 1156-1163. https://doi.org/10.1128/JCM.02980-14

[15] Aminu, M., Okachi, E.E., Abubakar, S.M. and Yahaya, A. (2013) Prevalence of Hepatitis B Virus Surface Antigen among Healthy Asymptomatic Students in a Nigerian University. Annals of African Medicine, 12, 55-56. https://doi.org/10.4103/1596-3519.108257

[16] Pido, B. and Kagimu, M. (2005) Prevalence of Hepatitis B Virus (HBV) Infection 
among Makerere University Medical Students. African Health Sciences, 5, 93-98.

[17] Komas, N.P., Bai-Sepou, S., Manirakiza, A., Leal, J., Bere, A. and Le Faou, A. (2010) The Prevalence of Hepatitis B Virus Markers in a Cohort of Students in Bangui, Central African Republic. BMC Infectious Diseases, 10, 226. https://doi.org/10.1186/1471-2334-10-226

[18] Mboto, C.I. and Edet, E.J. (2012) Prevalence and Risk Factors of Hepatitis B Virus Infection among Students in University of Uyo. International Journal of Modern Biology and Medicine, 2, 101-111.

[19] Lemoine, M., Shimakawa, Y., Njie, R., Taal, M., Ndow, G., Chemin, I., et al. (2016) Acceptability and Feasibility of a Screen-and-Treat Program for Hepatitis B Virus Infection in the Gambia: The Prevention of Liver fibrosis and Cancer in Africa (PROLIFICA) Study. The Lancet Global Health, 4, e67-e559.

[20] Lim, M.K., Franceschi, S., Vaccarella, S., Ju, Y.H., Oh, J.K., Kong, H.J., et al. (2009) Sexual Activity and Hepatitis B and C Virus Infection among Young Adults after Introduction of a Vaccination Program an Area of High Endemicity. Journal of Epidemiology, 19, 213-218. https://doi.org/10.2188/jea.JE20081010

[21] Stabinski, L., Reynolds, S., Ocama, P., Laeyendecker, O., Serwadda, D., Gray, R.H., et al. (2011) Hepatitis B Virus and Sexual Behavior in Rakai, Uganda. Journal of Medical Virology, 83, 796-800. https://doi.org/10.1002/jmv.22051

[22] Heikel, J., Sanchez, S., Bouqdir, F.H., Lila Rich, B., Radouani, F., et al. (1999) The Prevalence of Sexually Transmitted Pathogens Presenting to a Casablanca STD Clinic. European Journal of Epidemiology, 15, 711-715. https://doi.org/10.1023/A:1007639928462

[23] Lemoine, M., Nayagam, S. and Thursz, M. (2013) Viral Hepatitis in Resource-Limited Countries and Access to Antiviral Therapies: Current and Future Challenges. Future Virology, 8, 371-380. https://doi.org/10.2217/fvl.13.11

[24] World Health Organization (2015) Guidelines for the Prevention, Care and Treatment of Persons with Chronic Hepatitis B Infection. World Health Organization. http://www.who.int/hiv/pub/hepatitis/hepatitis-b-guidelines/en/

[25] Andersson, M., Rajbhandari, R., Kew, M., Vento, S., Preiser, W., et al. (2015) Mother-to-Child Transmission of Hepatitis B Virus in Sub-Saharan Africa: Time to Act. The Lancet Global Health, 3, e358-e359.

[26] N’dri-Yoman, T., Anglaret, X., Martin, E., Attia, A., Polneau, S., Toni, T., et al. (2010) Occult HBV Infection in Untreated HIV-Infected Adults in Ivory Coast. Antiviral Therapy, 15, 1029-1034. https://doi.org/10.3851/IMP1641

[27] Maldonado-Rodriguez, A., Cevallos, A.M., Rojas-get, O., Enriquez-Navarro, K., Muñoz Álvarez, M.T. and Lira, R. (2015) Occult Hepatitis B Virus Co-Infection in Human Immunodeficiency Virus-Positive Patients: A Review of Prevalence, Diagnosis and Clinical Significance. World Journal of Hepatology, 7, 253-260. https://doi.org/10.4254/wjh.v7.i2.253

[28] Bottero, J., Boyd, A., Gozlan, J., Lemoine, M., Carrat, F., Boo, N., et al. (2013) Performance of Rapid Tests for Detection of HBsAg and Anti-HBsAg in a Large Cohort, France. Journal of Hepatology, 58, 473-478. 
Submit or recommend next manuscript to SCIRP and we will provide best service for you:

Accepting pre-submission inquiries through Email, Facebook, LinkedIn, Twitter, etc. A wide selection of journals (inclusive of 9 subjects, more than 200 journals)

Providing 24-hour high-quality service

User-friendly online submission system

Fair and swift peer-review system

Efficient typesetting and proofreading procedure

Display of the result of downloads and visits, as well as the number of cited articles Maximum dissemination of your research work

Submit your manuscript at: http://papersubmission.scirp.org/

Or contact ojepi@scirp.org 